\title{
水膜振動の三次元特性と音圧レベルの推定に関する研究
}

\section{3-D characteristics of Nappe Oscillations and Estimation of Sound Pressure Levels}

\author{
建設省土木研究所 正員 角 哲也 Tetsuya SUMI \\ (株)栗本鉄工所 正員 中島 康夫 Yasuo NAKAJIMA
}

The author has outlined three-dimensional characteristics of nappe oscillations for explaining the effect of spoilers. Full-scale models have provided the common tendency of Sound Pressure Levels of the Low Frequency Air Vibration under the increase of the overflow depth of weirs. Various combinations of the opening of weir nappes have confirmed the effect of spoilers for restricting the oscillation within narrow limits as well as dicreasing peak Sound Pressure Levels. The author has also proposed the measure to estimate Sound Pressure Levels about the weir width, hight, overflow depth and the distance from the weir.

Keywords: Nappe Oscillation, Low Frequency Air Vibration, Sound Pressure Level, Overflow Weir, Spoiler

\section{1.はじめに}

越流型ゲートや砂防ダム等において、ある特定の越流水深になると水膜が高いレベルの振動現象を起こす ことがあり、ゲートが振動したり低周波空気振動が発生して問題となっている。この水膜振動現象は、水 膜、水膜背後の空洞、ゲート形状による水膜放出部特性、落下高などが複雑に関係したものであるため、従 来から発生源と增幅機構の考え方に混乱が生じている。

フラップゲート等のように水膜放出部であるゲート自体が弾性支持された場合には、自励振動が発生する 条件を検討した研究1),2があるが、砂防ダムのような固定堰においても同種の現象が見られることから、水膜 自体の特性を解明する必要がある。水膜に関するこれまでの研究 $33,44,5), 6,7), 8)$ によれは、振動の発生には、落 下する流速による動的な不安定性と、それに抵抗する水膜の厚さが関係しており、背後の空洞や気柱などは 増幅機構として作用していることが明らかとなっている。

本報文は、この振動機構を軎付けるために、水膜の越流幅を変えられる三次元模型を用いて振動発生条件 と発生周波数を調查したものである。また、徉来から振動防止対策として採用されている水膜分断スポイ ラーの音圧レベル低隇効果を確認し、越流型ゲートの設計における振動発生条件の特定と低周波音圧レベル の予測を試みるものである。

\section{2. 実験方法}

実験装置は、図ー 1 に示す落下高 $\mathrm{H}=2.5 \mathrm{~m}$ 、最大越流幅 $\mathrm{B}=6 \mathrm{~m}$ の越流型ゲート模型で、実物ゲートの一部分 を等大に抽出したものと考える。ダートに相当する部分には刃形ぜきを水面に対して 400の起立角で固定して おり、ゲート部における振動は発生しないものとする。図ー2に、越流幅および水膜分断形状を示すが、これ らは非越流板を任意位置に設置することにより变化させており、端に非越流板がある場合には側壁から開放 されていると判断した。また、落下高については、他の模型を用いて $\mathrm{H}=1.5 \sim 3.1 \mathrm{~m}(\mathrm{~B}=0.88,1.9 \mathrm{~m})$ の範囲 で変化させており、検討を行った実験条件は表-1に示すとおりである。

低周波空気振動の音圧レベルは、図ー3に示すように最大越流幅に等しい $6 \mathrm{~m}$ 下流の地点において低周波音 レベル計(リオン製NA17)で定点測定し、音圧レベルの隇衰特性を検討する場合のみ水膜中心線上を上下流方

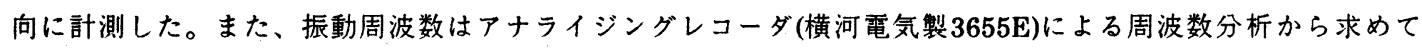
いる。写真一1に、代表的な水膜振動状況 $\left(\mathrm{B}=6.0 \mathrm{~m}, \mathrm{H}=2.5 \mathrm{~m}, \mathrm{~h}=4.6 \mathrm{~cm}, \mathrm{f}_{\mathrm{r}}=21.5 \mathrm{~Hz}\right)$ を示す。 

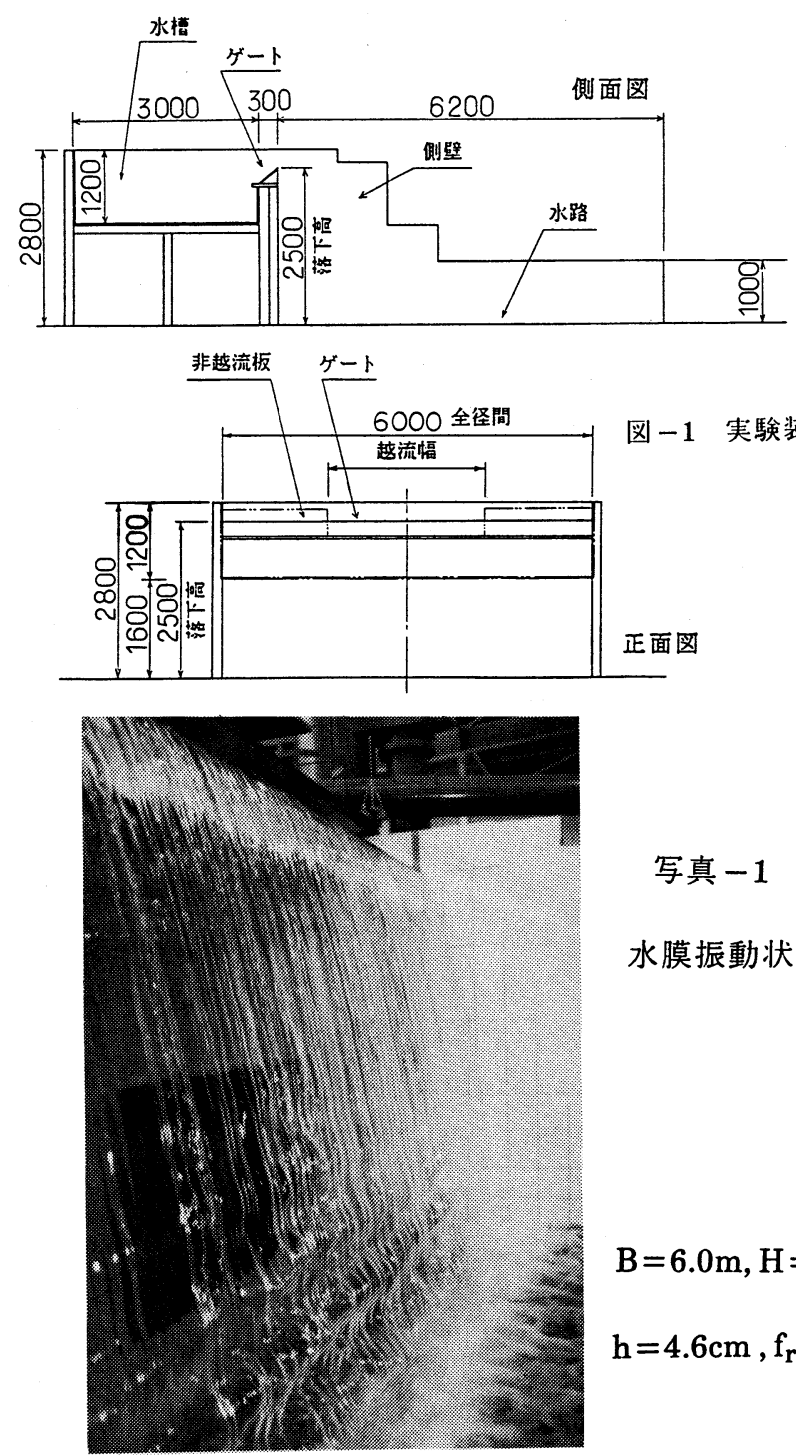

図 - 1 実験装置 圈现 正面図

写真 -1

水膜振動状況
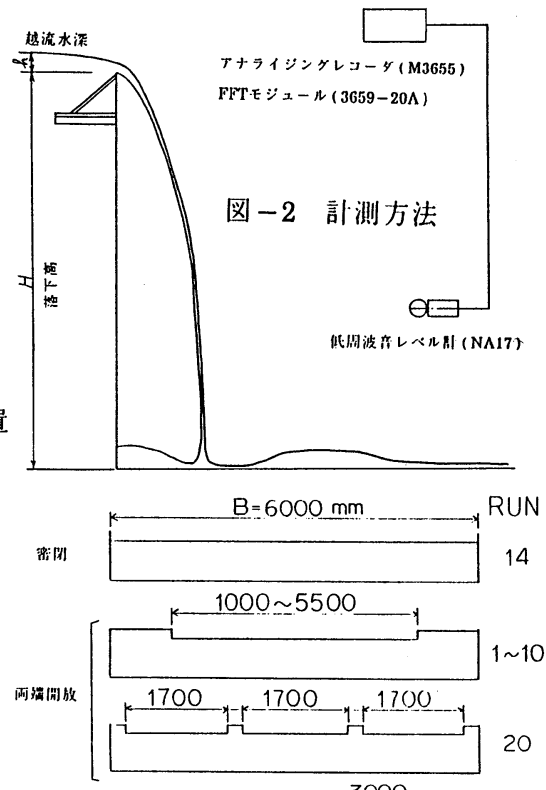
踏分闲放

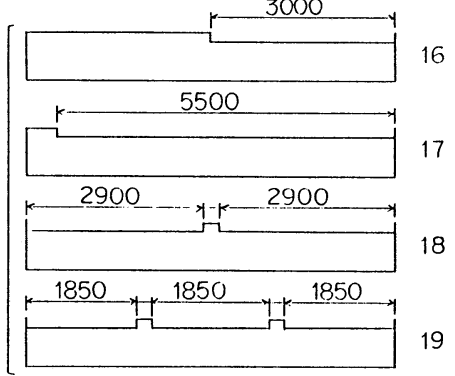

図 - 3 水膜分断形状

$\mathrm{B}=6.0 \mathrm{~m}, \mathrm{H}=2.5 \mathrm{~m}$

$\mathrm{h}=4.6 \mathrm{~cm}, \mathrm{f}_{\mathrm{r}}=21.5 \mathrm{~Hz}$

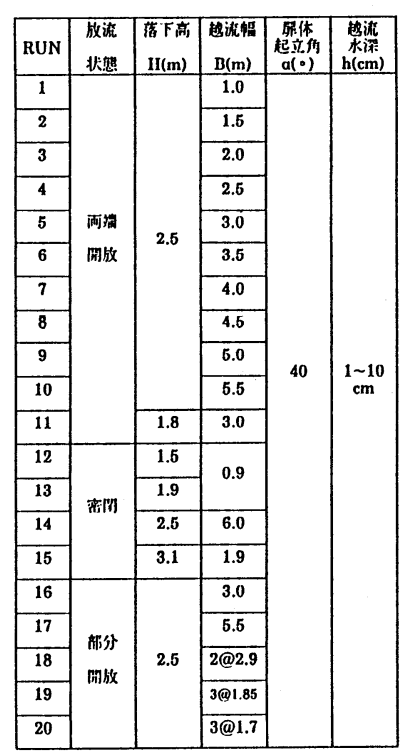

表 -1 実験条件 


\section{3. 低周波空気振動事例}

図ー4に、屝高 $4.2 \mathrm{~m}$ 、径間長 $10.8 \mathrm{~m}$ の越流型の $2 \mathbf{E}^{-}$式ローラダートで計 測された低周波音圧レベル(SPL)と越流水深(h)の関係を示す。測定ゲート 以外の放流の影響で計測時により起点音圧レベルが異なるため、個々の 值は一致しないが、15 20cm程度で最大音圧を与える傾向は一致してい る。なお、実物ゲートには振動防止用のスポイラーが設置されている が、計測はこれを取りはずしてその有効性を確認したものである。

図ー4には、可聴域における聴音レベル(A特性)の変化も合わせて示し ているが、顕著なピークを有する低周波域の傾向とは異なり、実機の計 測において低周波音特性を重視すべきことを示唆している。

\section{4. 実験結果}

\section{(1) 越流幅の効果}

落下高 $2.5 \mathrm{~m}$ の一定条件において、越流幅を $1.0 \mathrm{~m} \sim 5.5 \mathrm{~m}$ と変化させた場 合の音圧レベルの変化を図ー5に示す。図には、水膜振動の大きさを比較 するために次式で定義されるパワーレベル(PWL)を用いている。

$$
\begin{aligned}
& \mathrm{PWL}=\mathrm{SPL}(\mathrm{r})+20 \log \mathrm{r}+8(\mathrm{~dB}) \\
& \text { ここに、 } \mathrm{r} ; \text { 水膜から測定点までの距離 }(\mathrm{m}) \\
& \mathrm{SPL}(\mathrm{r}) ; \mathrm{r} \text { 地点での音圧レベル }(\mathrm{dB})
\end{aligned}
$$$$
\mathrm{SPL}(\mathrm{r}) ; \mathrm{r} \text { 地点での音圧レベル }(\mathrm{dB})
$$ \\ SPL(r);r地点での音圧レベル $(\mathrm{dB})$}

越流幅にかかわらず、ある特定の越流水深でPWLが最大となる傾向は 先に示した実物ゲートと同梯であるが、越流幅の増加により最大 PWL (以下 $\mathrm{PWL}_{\max }$ と呼ぶ) を与える越流水深 (以下 $\mathrm{h}_{\max }$ と呼ぶ) が大きく なっていることが確認される。

また、低周波空気振動を対象としない越流水脈の落下騒音の研究 ${ }^{9} に よ$ れば、落下音のPWLは越流幅と落下高と水脈の質量によって示される水 流の落下エネルギーに関係すると考えられる。しかしながら、今回得ら れたPWL $\mathrm{max}_{\max }$ 、後述するように、越流幅に関して水流の落下エネルギー だけでは説明されず、越流幅により振動レベルが変化して、単位幅当た りの低周波音のPWLが異なっていることが考えられる。

\section{(2) 水膜分断の効果}

水膜の端部を側壁から離して開放したRUN 5 と 16 およびRUN 9 と 17 を比較すると、図一6に示すように同じ越流幅3.0、5.0mにおいて $\mathrm{PWL}_{\max } に$ 約 $10 \mathrm{~dB}$ の相違があり、両端を開放すると音圧レベルが低減さ れる。しかしながら、RUN 14 と 17 ではわずか1dBの差しかなく、片端 のみの開放では水膜振動に大きな影響を及はさない。

次に、水膜の中央における分断においては、RUN 18、19、20 と分断 籄所が增えるほどPWL max $_{\max }$ が低下し、水膜を中央で分断したRUN 18 と端 部で分断したRUN 17 が同程度であることは興味深い。なお、越流幅 $6 \mathrm{~m}$ における今回の最大であるRUN 14 と最小であるRUN 20 の PWL $\mathrm{Pax}_{\max }$ の差 は約18dBである。

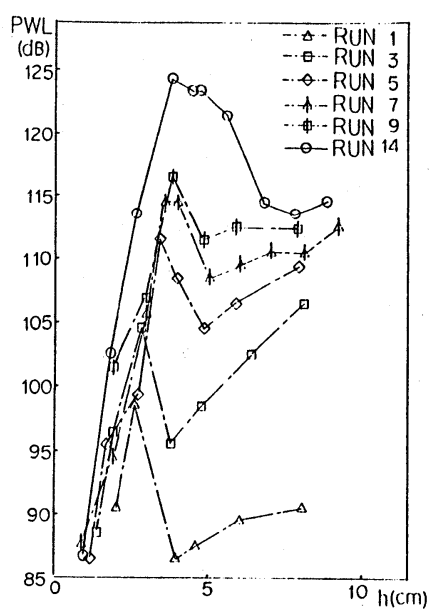

図 -5 パワーレベル特性 (1)

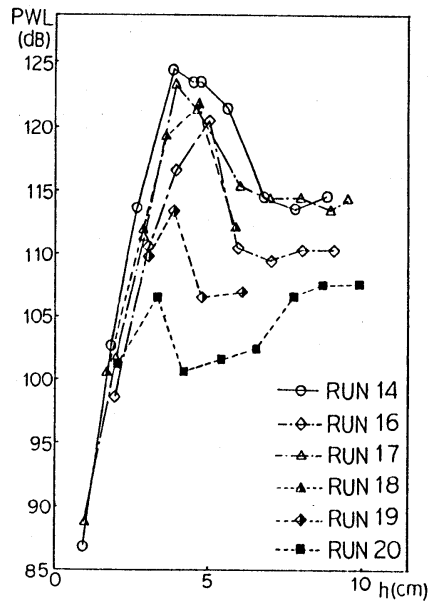

図 -6 パワーレベル特性 (2)

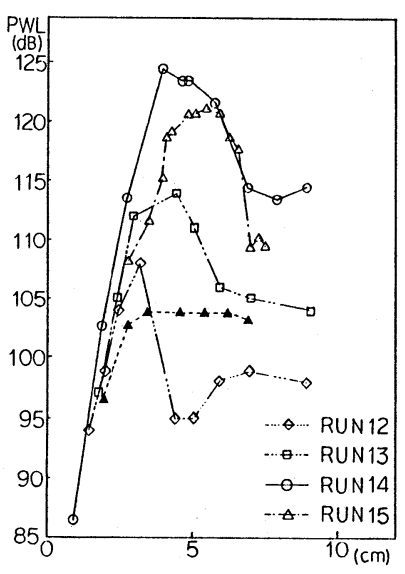

図 -7 パワーレバル特性 (3) 


\section{(3) 落下高の効果}

図ー7に落下高の異なるRUN 12〜15の音圧レベルを示すが、図一5の越流幅の場合と同様に、落下高が 大きくなるに従って、PWL $\mathrm{max}_{\max }$ よび $\mathrm{h}_{\max }$ が大きくなっている。特に、RUN 12 と 13 は同一越流幅である が約6dBの差があり、水流の落下エネルギーのPWLの差よりもかなり大きな結果である。また、RUN $15 に$ ついては、全実験条件の中で最も大きい $\mathrm{h}_{\max }$ を示しており、「落下高が大きく、流速が增大するほど厚い 水膜でも振動する」という、これまでの研究成果を裏付けるものとなっている。なお、RUN 14 と 15 が逆

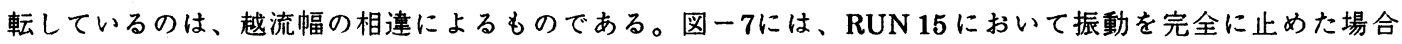
の音圧レベルも合わせて示しているが、これが水流による落下エネルギーに相当していると考えられ、こ こでは約18dBの差が認められる。

\section{(4) 音圧レベル最大時卓越周波数}

低周波音レベル計の出力波形から求められた卓越 周波数を図ー8に示すが、越流幅に関してほほ一定で あり、水膜振動は周波数に関して2次元性を保ってい ると考えられる。一方、落下高に関しては $\mathrm{H}=1.8 \sim 2.5 \mathrm{~m}$ 範囲でほほ21 22Hzであり、 $\mathrm{H}=3.1 \mathrm{~m}$ の $27 \mathrm{~Hz}$ と $\mathrm{H}=1.5 \mathrm{~m}$ の $20 \mathrm{~Hz}$ のみが異なる傾向を示して

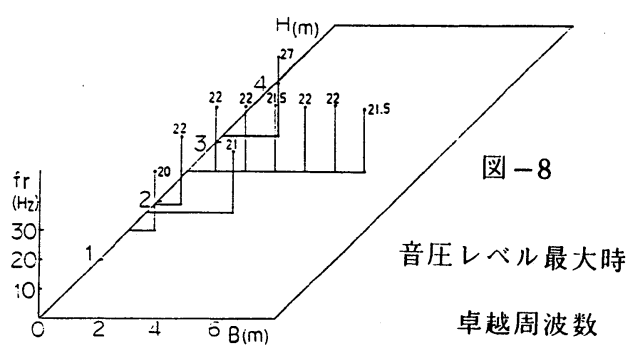
いる。従来から、落下高が周波数を決定する報告が

示されており、落下水膜に含まれる波数 (Schwartzの $\mathrm{k}+1 / 4$ 則の $\mathrm{k}$ ) が増大する考え方と同様の結果と考えら れるが、実験条件が少ないために、明確な結論を導くことは困難である。

\section{(5) 音圧レベル隇衰特性}

図ー9にRUN 19、h=5.5cmにおける水膜中央断面内の音圧レベル分布を示す。これより、低周波空気振 動は水膜全体の面音源ではなく落下点に扔ける線音源であることは明確である。また、その分布特性は、 水平下流、鉛直方向ともに等方的と考えられるが、底面付近は反射の影響で若干高い音圧レベルを示して いる。

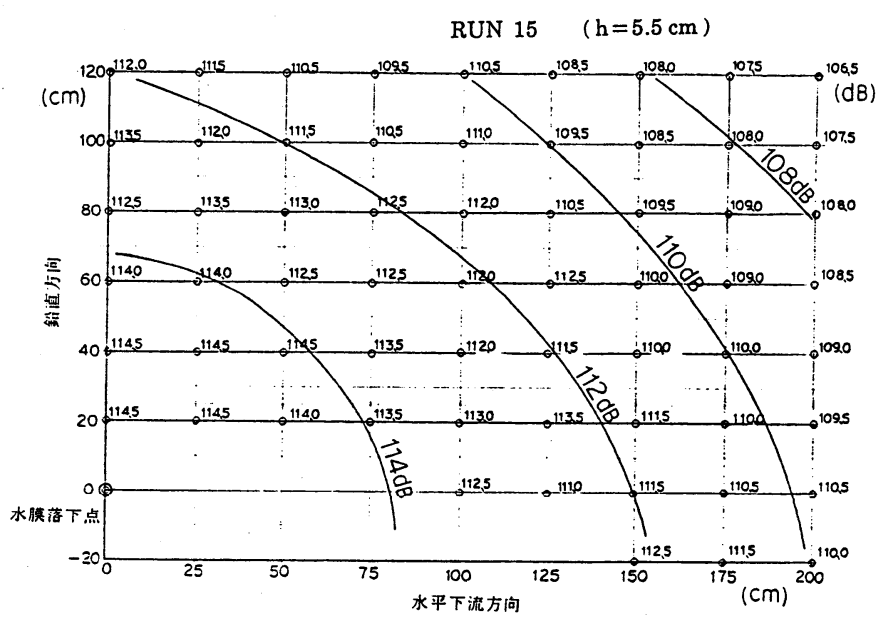

図-9 音圧レベル分布

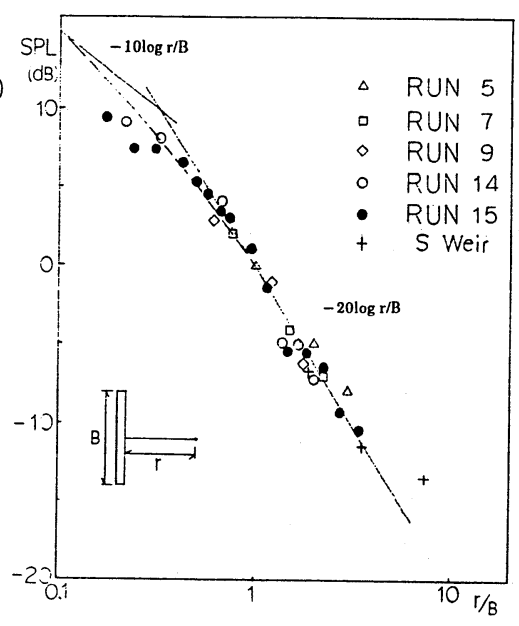

図-10 音圧レベル減衰特性 
そこで、水膜を図ー10に示すように幅Bの線音源と考え、測定点までの無次元距離 $\mathrm{r} / \mathrm{B} て ゙ \mathrm{SPL}(\mathrm{r})$ を整理す ると図のように実験条件にかかわらず一定の減衰傾向を示すことになる。これは、騒音の減衰特性9)と同様 であり、 $\mathrm{r} / \mathrm{B} \leqq 0.2$ 程度で倍距離 $3 \mathrm{~dB}$ の無限長線音源 $(\mathrm{SPL}(\mathrm{r})=\mathrm{PWL}-20 \log r-8) 、 \mathrm{r} / \mathrm{B} \geqq 1.0$ 程度で倍距離 $6 \mathrm{~dB}$ の有限長線音源 $(\mathrm{SPL}(\mathrm{r})=\mathrm{PWL}-10 \operatorname{logr}-8)$ に近似される。ここで図ー10においては、水膜端部が側壁に接 している場合に、側壁が音響的に反射面となって音源が長くなる (音響映像)ため、減裏特性をもとに(2)式 に示す越流幅の補正を近似的に行っている。

$\mathbf{B}^{\prime}=\mathbf{a} \cdot \mathbf{B}$

ここに、 $\mathrm{a}$; 越流幅補正係数 (1.5 再端密閉、 1.25 片端開放、1.0 両端開放)

\section{(6) 最大音圧を与える越流水深}

図ー5 7に示したPWLと越流水深の関係から、 $\mathrm{h}_{\max }$ を越流幅ごとに示したものが図ー11である。 両端開放（RUN 1 10)条件においては、越流幅 の増大とともに $\mathrm{h}_{\max }$ が大きくなっており、長径間

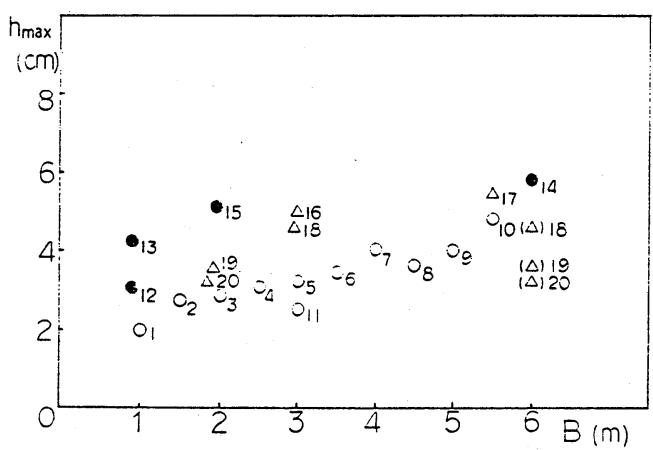

図一-11 音压レベル最大時越流水樑

になるほど水膜の厚い状態でも振動することになる。この理由は、水膜端部では縮流の影響によりゲート 部での越流幅と落下点の水膜幅が異なり、特に越流幅が小さい場合には落下点付近の水膜が厚くなってし まうためと考えられる。また、スポイラーで水膜を分断したRUN 19 と 20 の場合には、複数の水膜が存在 しても $\mathrm{h}_{\max }$ は単独の場合と同様と考えられる。両端密閉の場合および落下高の影響については、明確な結 論を導くことは困難であるが、落下高が高く、密閉状態であるほど $\mathrm{h}_{\max }$ が大きくなるものと考えられる。

\section{5. 音圧レベルに関する考察}

落下音による音圧レベルは、越流水膜の落下により発生する音のエネルギーが越流水膜の落下エ不ル ギーに比例すると考える ${ }^{9}$ 。

$$
\mathrm{W}=\mathrm{a} \cdot \mathrm{U}
$$

$$
\text { ここに、W; 音のエネルギー、 }
$$

U;落下エネルギー、

$a$; 定数

落下エネルギーをポテンシャルエネルギーで表わすと次式になる。

$$
\mathrm{U}=\mathbf{m} \cdot \mathbf{g} \cdot \mathbf{H}
$$

$$
\text { ここに、 } \mathrm{m} \text {; 水の質量、 } \mathrm{g} \text {; 重力加速度 }
$$

ここで、質量は流量に相当し、堰あるいはゲートの越流公式により (5)式で示され(4)式は(6)式となる。

$$
\mathrm{m}=\rho \cdot \mathrm{CB} \mathrm{h}^{3 / 2}
$$

ここに、 $\rho$; 水の密度、 $\mathrm{C}$; 流量係数、 $\mathrm{B}$; 越流幅、

$$
\mathbf{h} \text {; 越流水深 }
$$

$$
\mathrm{U}=\rho \mathrm{g} \mathrm{CB} \mathrm{h}{ }^{3 / 2} \mathrm{H}
$$

次に、落下水膜が振動して落下音以外に空気振動を発生する場合 に、振動振幅に相当する係数Kを導入して落下エネルギーを補正する と(7)式となり、最終的に(3)式は(8)式となる。

$$
\begin{aligned}
\mathrm{U}^{\prime}=\mathrm{K} \cdot \mathrm{U} & =\mathrm{K} \cdot \mathrm{\rho gCBh}^{3 / 2} \mathrm{H} \\
& \text { ここに、 } \mathrm{U}^{\prime} ; \text { 水膜振動を考㢝した落下エネルギー }
\end{aligned}
$$

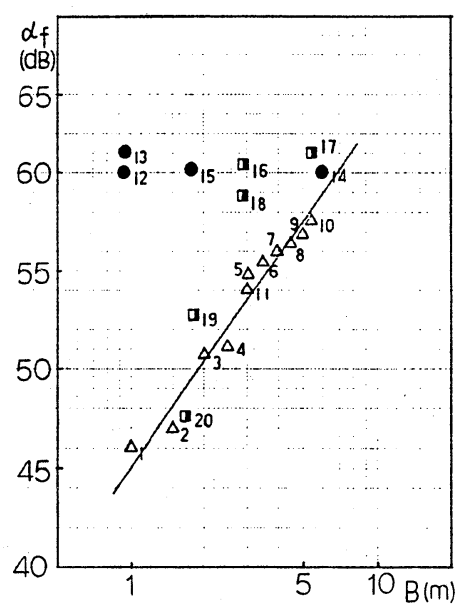

図-12 音王レベル補正値 


$$
\begin{aligned}
\mathrm{W}=\mathrm{a} \cdot \mathrm{K} \cdot \mathrm{U} & =a \cdot \mathrm{K} \cdot \mathrm{\rho gCBh}^{3 / 2} \mathrm{H}=\mathrm{A} \cdot \mathrm{K} \cdot \mathrm{Bh}^{3 / 2} \mathrm{H} \\
& \text { ここに、A;定数 }(=\mathrm{a \rho g} \mathrm{C})
\end{aligned}
$$

これを、対数変換すると(9)式となる。

$$
\begin{aligned}
\text { PWL }= & 10 \log \left(\mathrm{A} \mathrm{K} \mathrm{B} \mathrm{h}{ }^{3 / 2} \mathrm{H}\right) \\
= & 10 \log \mathrm{A}+10 \log \mathrm{K}+10 \log \mathrm{B}+15 \log \mathrm{h}+10 \log \mathrm{H} \\
= & a_{\mathrm{f}}+10 \log \mathrm{B}+15 \log \mathrm{h}+10 \log \mathrm{H} \\
& \text { ここに、 } a_{\mathrm{f}} ; \text { 定数項および振動振幅による補正項 }(=10 \log \mathrm{A}+10 \log \mathrm{K})
\end{aligned}
$$

そこで、(9)式を用いて、各実騃条件ごとに $a_{\mathrm{f}}$ を求めたものが図一12である。図より、知はスポイラーで水 膜を分断したものも含めて、両端が開放された水膜は越流幅の対数項に関して線形である。一方、両端を密 閉したものは、越流幅にかかわらず約 $60 \mathrm{~dB}$ である。これより、 $\mathrm{a}_{\mathrm{f}}$ は(10)式で近似されるものと考える。

$$
\begin{aligned}
a_{\mathrm{f}} & =60 & & \text { (両端密閉) } \\
& =9+18 \log \mathrm{B} & , \mathrm{B} \leqq 6.0 \mathrm{~m} & \text { (片端または両端開放) }
\end{aligned}
$$

なお、 $a_{\mathbf{f}}$ の補正は水膜両端の縮流に関係し、水膜幅が $6 \mathrm{~m}$ 以上の場合は両端密閉の場合とほほ同様になるもの と考えられる。

従って、最終的な低周波音圧レベルの予測式は、距離隇衰項も導入して(11)式で与えられる。

$$
\begin{aligned}
& \mathrm{SPL}(\mathrm{r})=10 \log \mathrm{B}^{\prime}+15 \log \mathrm{h}_{\max }+10 \log \mathrm{H}-20 \log \mathrm{r}+52 \quad \text { (再端密閉) } \\
& =10 \log \mathrm{B}^{\prime}+15 \log \mathrm{h}_{\max }+10 \log \mathrm{H}-20 \log \mathrm{r}+18 \log \mathrm{B}+1 \\
& \text { (B } \leqq 6.0 \mathrm{~m} \text { かつ片端または両端開放) }
\end{aligned}
$$

\section{6. おわりに}

本実験では越流幅および水膜分断の効果を調查したが、水膜振動は周波数に関して二次元性を保ってい る。しかしながら、音圧レベルが最大となる越流水深やその音圧レベルは越流幅の影響を受けて二次元モデ ルだけでは説明されない結果となった。また、越流水膜を分断したり端部を開放したりすると、水膜振動を 停止させることは必ずしもできないが音圧レベルの低隇は可能であり、従来の対策の有効性が確認された。

また、水膜振動が発生する各越流幅における越流水深の領域が特定され、長径間ほど振動発生越流水深が 大きくなる可能性が示された。さらに、低周波音圧レベルは、水流のエネルギーに比例する落下エネルギー と、主に越流幅に依存する非線形な水膜振動エネルギーが複雑に絡み合っており、本実験で提案した予測式 について、実機の計測データをもとに検証を行う必要がある。

\section{7. 参考文献}

1)萩原: フラップゲートおよびナップの自励振動、土木学会論文集、第357号/II -3、1985年

2) Petricat: "Vibration tests on weir and bottom gate",Water Power, March(1958)

3) Hagerty : "Study of the Stability of Plane Fluid sheets"Jr. of Applied Mechanics.Dec.(1955)

4) Schwartz :"Edgetone and Nappe Oscillation", Jr. of the Acoustic Society of America, 1966-3

5)Kolkman: "Instability of a Vertical Water-Curtain Closing an Air -Chamber",IAHR ,(1972)

6)大久保·角: 鉛直落下水膜の振動特性、土木学会第 43 回年講、1988年

7)角·大久保 : フラップゲート越流水膜の振動特性、土木学会第 43 回年講、1988年

8)中島·角:三次元性を考慮した水膜振動特性、土木学会第44回年講、1989年

9)川崎重工業: 水門越流水騒音の研究、1981年 